\title{
The Effectiveness of Swimming Towards Asthma Complaint Reduction and Improvement of Ability on Peak Expiratory Flow to Children
}

\author{
H B Bafirman ${ }^{1 *}$, Khairuddin ${ }^{1}$, Syahrastani $^{1}$, Y Elsa $^{2}$ \\ ${ }^{1}$ Universitas Negeri Padang, Prof. Dr. Hamka, Padang, Indonesia \\ "Corresponding author.Email: bafirman@gmail.com
}

\begin{abstract}
Children with asthma symptoms have limitation on conducting physical activity. For instance, they are easily to get tired and they are less excited. Furthermore, they are socially and emotionally unacceptable for the peer group due to their low ability in various physical activities. If this conditions are left untreated, the children will experience loss of cardiovascular fitness and other negative effects such as physical disruption, limited motor development, and lower physical fitness levels. The objective of this study was to assess whether swimming excercise effectively lower asthma symptoms and increase Peak Expiratory Flow (PEF) to children with asthma symptoms. This research used qualitative and quantitative type with action research design. The population of this research were elementary school students in Padang, West Sumatra, and the samples of this research were 25 five students who were taken by accidental sampling. The instruments of asthma symptoms were diagnosed by experts (doctors), questionnaires, and interviews. Instruments of PEF capability with peak flow meter. The data analysis used descriptive statistics, and t-test with $95 \%$ confidence level. The results of the study show that (1) swimming sport activities effectively decreased children's asthma symptoms; and (2) effective swimming activities significantly improved the ability of PEF to children with asthma symptoms ( $\mathrm{p}$ $<0.05)$.
\end{abstract}

Keywords: Swimming, asthma complaint reduction, peak expiratory flow

\section{INTRODUCTION}

Asthma is a chronic disease that is often suffered by children. Asthma is very disturbing for those who suffered it, especially children. It is potential to interfere children's growth and development. In addition, asthma suffered by children can make them not feel free to do activities they want such as learning activities at school, sports, playing a particular instrument, dancing, and other activities. As a result, children who have asthma complaints may suffer socially and emotionally. They are less acceptable to their peer group because of their low ability to perform physical activities. This low ability is indicated by limited physical activity, fatigue, lack of enthusiasm, and low levels of physical fitness.

Asthma complaints are triggered by various causative factors, which are mostly caused by atopy or allergic factors. Causes and triggers of asthma include house dust, animal fur, cigarette smoke, mosquito repellent smoke, environmental pollution, and industrial food product. The environmental pollution is in the form of increased penetration of ozone, sulfur dioxide (SO2), nitrogen oxide (NOX), diesel particles, polluted smoke particles (PM10) which are produced by industries and motor vehicles. The endustrial food products with artificial colors (for example tartazine), preservatives (for example metabisulphite), and vetsin (for example monosodium glutamate-MSG) can also trigger asthma (Ratih et al. 2010). Other conditions that can trigger asthma are activities, infectious diseases, emotions or stress. Those things are related to the breath channel. Since the breath channel is very sensitive to various stimuli, both from within and outside the body, this excessive sensitivity causes the narrowing of the whole airway which triggers asthma (Abidin, 2002).

According to data from The Global Asthma Report in 2016, it was stated that the estimated number of asthma sufferers worldwide were 325 million people and asthma was included into 5 major causes of death with an increasing prevalence rate especially to children. In addition, complaints of asthma is a world health problem which does not only infect people in developed countries but also in developing countries (Sundaru, 2007). Furthermore, Ministry of Health of the Republic of Indonesia (2012) stated that asthma is included into 10 major causes of illness and death with $12,500,000$ patients of the 250 million people in Indonesia, $10 \%$ suffer from asthma. It is feared that 
people with asthma will increase in children aged 6-12 years or who are still in primary school (WHO, 2006).

Based on a modified questionnaire from International Study of Asthma and Childhood (ISAAC) questionnaire about the risk factor for asthma, which was given to elementary school students aged 6-7 years in Padang,West Sumatra, it was found that asthma prevalence among elementary school pupils aged 6-7 years was 8\% (Afdal et. al., 2009). In addition, the annual report of Padang City Health Service year 2009 to 2011 shows the incidence of asthma increased from $13.3 \%$ in 2009 to $15.4 \%$ in 2010 and $15.4 \%$ in 2011 (Dinkes Kota Padang, 2011; Masrizal, 2016).

Children who are suffered from asthma may expericence physical and psychological changes. Physical changes occur due to recurrent asthma. The changes are barrel-shPEFd chest, elevated shoulders, zygomatic fracture, circles around the eyes, nose shrink and upper teeth protruding (Joseph, 2007). Clinical symptoms that occur to children with asthma include dry cough, shortness of breath, wheezing (can be heard), fatigue, talk with short broekn phrases, panting, insomnia, and rapid heartbeat (Wong, 2003). Clinical symptoms that occur to children with asthma include feeling inferior, feelings of helplessness, no hope, feeling confined or unable to move freely. As a result, children with asthma feel loss of self-esteem.

Asthma can be cured when the asthma complains are controlled. When it is not controlled, asthma will disrupt the quality of life and cause loss of school time (Supriyatno 2005). Asthma can be caused by several factors, namely genetic factors and trigger factors. Genetic factors are talents in a person characterized by the presence of certain genes in a person with asthma. The gene is derived from parents. Meanwhile the trigger factor can be classified into a trigger factor from outside the body and inside the body (Aryandani, 2010; Pohan et al., 2003).

Law of the Republic of Indonesia Number 36 Year 2009, on Health, article 80 stated that: "The sport health promotes health and society". Sports activities which are done correctly, on the right time, regularly, and measureable is one of efforts to improve the quality of the body's organs. Thus, the health status can be improved. When patients with asthma do exercise regularly such as swimming, they can get improvement of cardiovascular fitness and pulmonary fentilation. Besides, swimmning strengthen the respiratory muscles (Jeng-Shing Wang and Wen-Ping Hung, 2009).

All movement during swimming involves almost all of muscles; improves the ability of the respiratory muscles, so swimming can be useful to overcome asthma complaints. Furthermore, swimming physical exercise is an aerobic exercise that has the highest value compared to other aerobic exercises. Besides, swimming is a fairly safe sport and it can be applied at all ages ranging from children, adults, elderly, and elderly.

Considering the various problems that have been raised above, the authors write a scientific article, which is based on authors' former research author, entitled "Effectiveness of Swimming Exercise Toward Asthma Complaint Reduction and Improvement of Peak of Expiratory Flow Ability for Children with Asthma Patients." This scientific work is expected to be a study material to address the asthma complaints experienced by the children, as well aas an effort to improve physical fitness of young people who have asthma complaints in order to build quality human resources.

\section{METHOD}

This research is qualitative and quantitative, action research. The research was conducted conducted in five months (June-October) 2017. This research used qualitative and quantitative type with action research design. The population of this research were elementary school students in Padang, West Sumatra, and the samples of this research were 25 five students who were taken by ascidental sampling. The instruments of asthma symptoms were diagnosed by experts (doctors), questionnaires, and interviews. Instruments of PEF (Peak Expiratory Flow) with units of liter/minute and Asthma Control Test. Measurement of PEF capability was done by using peak flow meter. Data analysis techniques was done in qualitative type by using the Spradley model, which were derived from the descriptive observation process, domain analysis, and focused observation. Data analysis technique was quantitative and it used descriptive statistics, variance analysis and t-test with $95 \%$ reability level.

\section{RESULT AND DISCUSSION}

\section{Result}

The Effectiveness of Swimming Sports in Reducing Asthma Complaints

After diagnosing children who were suspected of having asthma complaints to be involved as a sample, then the children were given a questionnaire to find out the asthma complaint they experienced. Children with asthma complaints were characterized by several indicators such as; shortness of breath, repeated wheezing, insomnia, rapid pulse / heart, coughing, and so on. Questions were given by providing Yes and No answers. The answer of "Yes" means the child experienced what was being asked. Meanwhile, the answer of "No" means the child did not experience what was being asked. The questions are drawn in the table 1 . 
Table 1. The Deskriptive Result

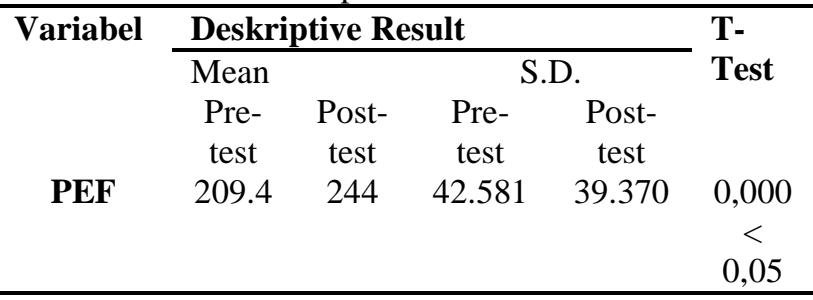

The percentage of complaints of children with asthma, who participated in sports activities swimming, between pre-test and post-test decreases. Those with shortness of breath decreased 6 people (24\%). Wheezing breath decreased 11 people (44\%). Breathpussy decreased 17 (68\%). Talk stammered 13 people (52\%). Chest is not good at rest 11 people (44). Frequently coughing 11 people (44\%). Less comfortable and difficult to sleep 12 people (48\%). Very breathless exercise breath 8 people $(32 \%)$. Asthma disrupts the study of 17 people (68\%). Fast pulse at rest of 9 people (36\%). Appetite reduced by 8 people $(32 \%)$. The rest of children who still felt the presence of asthma, on average they told that they have less asthma complaints by swimming. In addition, they no longer suffer asthma as often as before they do regular swimming.

The Effectiveness of Swimming Sports Toward the Ability of PEF to Asthmatc Children

Before conducting hypothesis test, the data which were already obtained were analyzed descriptively, then it was continued to the test of normality and test of linearity. After getting the result that the data were

Table 2. The Descriptive Result and Comparison of PEF Ability Between Pre-test and Pos-Test

\begin{tabular}{|c|c|c|c|c|c|c|c|c|c|c|c|}
\hline \multirow[t]{4}{*}{ No } & \multirow[t]{4}{*}{ Questions } & \multicolumn{10}{|c|}{ Answer } \\
\hline & & \multicolumn{4}{|c|}{ Pre-test } & \multicolumn{4}{|c|}{ Post-test } & \multicolumn{2}{|c|}{ Redudance } \\
\hline & & Yes & & $\mathrm{N}$ & & $\mathrm{Ye}$ & & No & & & \\
\hline & & $\mathrm{f}$ & $\%$ & $\mathrm{~F}$ & $\%$ & $\mathrm{f}$ & $\%$ & $\mathrm{~F}$ & $\%$ & $\mathrm{f}$ & $\%$ \\
\hline 1 & Hard to breathe & 18 & 72 & 7 & 28 & 12 & 48 & 13 & 52 & 6 & 24 \\
\hline 2 & The sound of wheezing & 19 & 76 & 6 & 24 & 8 & 32 & 17 & 68 & 11 & 44 \\
\hline 3 & Breath-pussy & 20 & 80 & 5 & 20 & 3 & 12 & 22 & 88 & 17 & 68 \\
\hline 4 & Talk stammered & 19 & 76 & 6 & 24 & 6 & 24 & 19 & 76 & 13 & 52 \\
\hline 5 & Chest is not good at rest & 19 & 76 & 6 & 24 & 8 & 32 & 17 & 68 & 11 & 44 \\
\hline 6 & Frequent coughing & 22 & 88 & 3 & 12 & 11 & 44 & 14 & 56 & 11 & 44 \\
\hline 7 & $\begin{array}{l}\text { Less comfortable and hard to } \\
\text { sleep }\end{array}$ & 21 & 84 & 4 & 16 & 9 & 36 & 16 & 64 & 12 & 48 \\
\hline 8 & Breath very shortness of exercise & 19 & 76 & 6 & 24 & 11 & 44 & 14 & 56 & 8 & 32 \\
\hline 9 & Asthma interferes with learning & 20 & 80 & 5 & 20 & 3 & 12 & 22 & 88 & 17 & 68 \\
\hline 10 & Fast pulse at rest & 16 & 64 & 9 & 36 & 7 & 28 & 18 & 72 & 9 & 36 \\
\hline 11 & Appetite reduced & 16 & 64 & 9 & 36 & 8 & 32 & 17 & 28 & 8 & 32 \\
\hline
\end{tabular}

\section{Discussion}

Swimming Sports Activity Reduce Asthma Complaints Suffered by Children

There are a lot of people who are suffered asthma in Indonesia. Consequently, this condition requires a normal and linear, the hypothesis test was done. The proposed hypothesis is that "Swimming effectively increase the ability of Peak of Expiration Flow (PEF) to children who are suffered asthma" as shown in the following table 2 .

Based on descriptive data, the mean of pre-test PEF was 209.4, and the mean of post-test was 244. This changes showed that there was a tendency of PEF improvement after treatment 34,6. After testing, the correlation of PEF values between before and after treatment was 0.880 , with a significance level of 0.000 . This means that the significance $<\alpha \quad(0,05)$, the correlation is strong and positive. As the result, swimming sport activities are significantly effective in increasing the ability of PEF to children's who are suffered asthma.

The research findings shows that (1) swimming sport activitiy effectively decrease asthma complaints suffered by children, and (2) swimming sports activity significantly increase the ability of PEF in children with asthma complaints. A decrease in asthma complaints through swimming exercise is evidenced by the decreasing of asthma complaints experienced by children, both quantitatively and people (68\%). Fast pulse at rest of 9 people $(36 \%)$. Appetite reduced by 8 people $(32 \%)$. The rest of children who still felt the presence of asthma, on average they told that they have less asthma complaints by swimming. In addition, they no longer qualitatively in response to questionnaires, diagnoses and interviews, as well as menint the ability of PEF to children's who are suffered asthma. 
asthma sufferers in Indonesia is known as complementary therapy (non-pharmacological). One of this non-pharmachological therapies can be done through swimming sports activities. Swimming sport activity trains all the respiratory muscles, starting from the chest, abdomen, shoulders which all move so that it can improve the condition of asthma complaints. An asthma complaint is triggered by dry air. When someone do swimming, breathing occurs near the surface of the water, the steam makes the incoming air is not dry. In addition, swimming can evoke confidence and vibrancy, and psychologically reduces the risk of attack.

Swimming sports activities have a reciprocal relationship with respiration. The recommended exercise for those with asthma is a mild and simple exercise. It is the appropriate evercise based on to the abilities of asthmatics (Ram, Robinson, Black, Picot, 2005). The physical exercise is designed for people with asthma with the goal of improving physical fitness, neuromuscular coordination by increasing respiratory muscle strength and confidence (Ram, Robinson, Black, Picot, 2005).

According to Ray, Pendergast, Lundgren (2008), it is believed that by swimming, there will be increased respiratory capacity, especially expiratory ability in asthmatics. Swimming can be very beneficial for elderly people who have experinced a decrease in lung capacity as a result of decreased lung function and decreased respiratory muscle endurance. In addition, swimming can also help children and adults with asthma. The results of several studies identify that swimming can reduce the severity of asthma and Chronic Obstructive Pulmonary Disease (COPD).

Swimming sport does not directly cure asthma complaints. In fact, swimmming strengthen the respiratory muscles and improve lung ventilation, thereby swimming reduces asthma risk and decreases asthma attacks. However, when swimming sport activities are done in a continuous and continuous manner, asthma complaints decrease and not be felt again. This is very different if people consume herbs preventing asthma throughout their life. The side effects of comsuming herbs will appear in the future.

Regular swimming with sufficient intensity give the same physiological benefits for both asthmatics or nonasthmatic. However, asthmatics get added values by swimming. In other words, those who suffered asthma, get physiological benefit as well as health benefit. This is due to the more efficient functioning of the respiratory system which includes: (1) the increased maximal breathing capacity, (2) the reduced volume of residual air (residual air) caused by reduced trapped air, and (3) the presence of more efficient lung ventilation patterns (Fitch, Morton, and Blanksby, 1976).

Furthermore, swimming increase the efficiency of the respiratory system so that the diffusion capacity is greater. There are some changes in the respiratory system which occur when people do swimming. They are (1) increased ventilation for a minute as a result of the increase in tidal volume and breath frequency, (2) increased ventilation efficiency: the amount of ventilated air at the same level of oxygen consumption will be lower, and (3) skeletal muscle which actively gets more oxygen fcompared to the respiratory muscles (Rogayah, 1998). Swimming can make the whole body work without risk of joint injury, making it suitable for all ages. So that the airways will not dry and trigger the occurrence of asthma.

\section{Effective Swimming Sport Activities Improve Ability of} PEF to Children Who Have Asthma Complaints

Assessment of the degree of asthma can be determined by monitoring the ability of the Peak Expiratory Flow (PEF). The degree of asthma is used to assess the level of asthma complaints. PEF examination is easy and simple to assess the weight of airway obstruction by using peak flow meter. Peak flow meter is a tool used to measure the amount of air flowing from a patient's lungs in one breath. This tool can help measure the amount of air coming from the lungs, and also serves to control the asthma of the patient. Peak flow meter is relatively cheap and can be taken anywhere, so the examination can not only be done in clinics, hospitals but can be done at home patients independently. However, not many people with asthma who understand and use it (PDPI, 2006).

The ability of PEF which is measured in liters / minute can give a warning showing pulmonary function decline and reflecting a narrowing or obstruction of the airways (Mangunegoro, 2004). Pressure from forced expiration causes the diaphragm to move and open up a wider orifice area. The value of PEF is influenced by several hundred milliliters of air starting from the full inflation of the lungs and by the strength of the chest and abdominal muscles (Sheikh et.al, 2000). The most common pathologic state affecting PEF is structural disturbance or function of the intrathoracic respiratory tract which increases airflow resistance. PEF is also disturbed by extrathoracic airway obstruction, a condition that restrict movement of chest wall or respiratory muscle function and integrity of the nervous system. In the restrictive process due to interstitial lung disease, loss of lung volume is due to increased pulmonary elastic recoil (Pedersen, et al., 1997). 
When asthma complaints occur, the more frequently used muscles are the intercostal muscles rather than the neurophysiological changes in the physiological exercise (Lori et.all, 2013). The better quality of the

Figure 1. Graph of comparrison of PEF ability between pre and post test

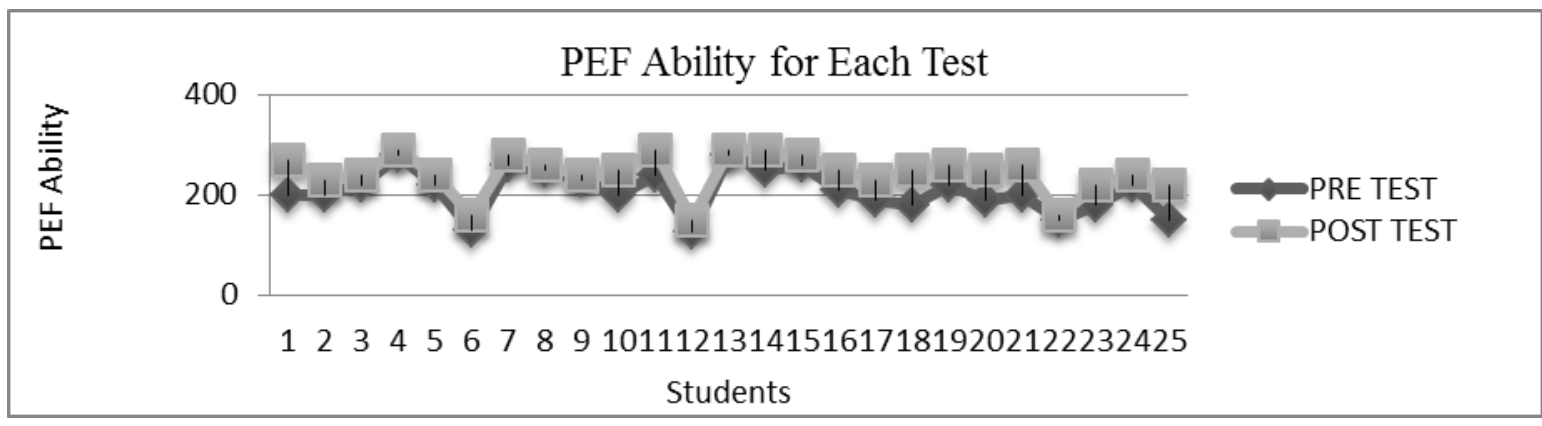

abdominis muscles, whereas the most important respiratory muscle is the diaphragm. Continuous use of the intercostal muscles will cause weakness of the respiratory muscles, thus a strengthening of the respiratory muscles for asthmatics (Shaffer, 2012) is required. Furthermore, swimming sport activity can improve the quality of life and contribute to improving motoric development (Elif Top, 2015). Besides, swimming is an effective nonpharmacological drug Intervention for children or adolescents with asthma (Jeng-Shing, Wen-Ping, 2009).

According to the research findings, PEF capability comparison between pre-test and post-test is according to the following graph.

In accordance with the above table, there is the improvement of ability of PEF from children with asthma between pre-test with post-test. The maximum velocity value of the current generated during expiration, usually occurs in the first 150 milliseconds of forced expiratory maneuver (Castile, 2006). Swimming involves almost all the major muscles of the body, especially the respiratory muscles. People who do regular swimming exercises indirectly have repeatedly exercised the respiratory muscles, thereby increasing the ability and endurance of the respiratory muscles, which in turn will have an impact on increasing the value of PEF.

Swimming sport activities are also considered as a means of recruitment, held in vast areas equipped with various game facilities (Gaunt, 2012). It is a great way to introduce swimming sports to kids through the game. Swimming sports can increase the hormone endorphins in the brain. It is believed to cause a comfort effect for a person and can eliminate the occurrence of stress. At the time of floating in the water, swimming can launch blood circulation to the brain which of course is very beneficial for the health of the body (Mc Govern, 2005).

Sports activities in the water provide a variety of physiological effects beneficial to the physic. Swimming has a direct reaction to the physical fitness of learners influences the spirit of learning. The physical fitness of the children characterizes the ability to adjust the functions of the organs of the body within psychological limits to the condiiton of the physical work environment in a sufficiently efficient manner without excessive fatigue. Thus, the children can still carry on the subsequent activities.

When children have better quality of the physical fitness, it will be easier for them to do their activites even in difficult circumstances. Vice versa if the children have poor physical fitness, it will be difficult for them to perform their duties. When sports activities are done well, regularly, measurable, they will form a good physical endurance power. The best management of asthma should be done early with a variety of preventive measures so that patients do not experience an asthma attack (Nugroho, 2008).

Swimming sport activities not only avoid asthma attacks, this sport can cure breathing problems such as snoring, mouth-breathing and so on (Matsumoto et.al, 1999). Through swimming the children can be happy. It also can improve the learning process, make children achieve faster development on cognitive, physical, and language (Fitch, Morton, Blanksby, 1976). Participation and encouragement of parents strongly determines the involvement and motivation of children performing regular and programmed swimming activities (Jennifer, 2014).

\section{CONCLUSION}

Based on the findings and discussions above, it can be concluded that (1) Swimming sport activities effectively decrease asthma complaints to children, and (2) sports activities significantly improve the ability of PEF to children who experience asthma complaints. To parents/guardians and teachers of Physical Education Sport and Health provide encouragement to the children who have asthma complaints so the children can do swimming regularly. 


\section{REFERENCES}

[1] Abidin, M., Angela, 2002. Mengenal, Mencegah dan Mengatasi Asma pada Anak Plus Panduan Senam Asma. Jakarta : Puspa Swara.

[2] Afdal, dkk., 2009. Faktor Risiko Asma Pada Murid Sekolah Dasar Usia 6-7 Tahun di Kota Padang. http://jurnal.fk.unand.ac.id.

[3] Aryandani, R., 2010. Anak Sehat Bebas dari Asma. Yogyakarta: Golden Book.

[4] Castile RG., 2006. Pulmonary Function testing in children. Dalam: Chemick V. Boat TF, Wilmott RW. Bush A, penyunting. Kendig's Disorder of the Respiratory Tract in Chuldren. Edisi ke-7. Philadelpia: Elsevier Inc: h. 168-85.

[5] Departemen Kesehatan, 2012. Asma di Indonesia. http//www.depkes.id.

[6] Dinas Kesehatan Kota Padang, 2011. Laporan Tahunan Penyakit Asma 2009,2010,2011.

[7] Elif Top, 2015. The Effect of Swimming Exercise on Motor Development Level in Adolescents with Intellectual Disabilities. American Journal of Sports Science and Medicine, Vol. 3, No. 5, 85-89 Available online at http://pubs.sciepub.com/ajssm/3/5/1 (C) Science and Education Publishing, DOI:10.12691/ajssm-3-5-1

[8] Fitch, A., R., Morton, and Blanksby, 1976. Effects of Swimming Training On Children With Asthma. Archives of Disease in Childhood,51, 190.

[9] Fuhlbrigge A., Peden D., Apter AJ., Boushey HA.,Camargo CA., Gern J., et al., 2012. Asthma outcomes : Exacerbation. J Allergy Immunol vol 129 hal 35-45.

[10] Gaunt T., Maffulli, N., 2012. Soothing suffering swimmers: a systematic review of the epidemiology, diagnosis, treatment and rehabilitation of musculoskeletal injuries in competitive swimmers. British Medical Bulletin, Volume 103, Issue 1, 1 September, 201. Pages 45-88, https://doi.org/10.1093/bmb/ ldr039

[11] GINA., 2016. Global Strategi For Asma Managemant and Prevention.Global Initiatif For Asma.

[12] ISAAC., Steering Committee, 1998. Worldwide variations in prevalence of asthma symptoms: the International Study of Asthma and Allergies in Childhood (ISAAC). Eur Respir J; 12:31535.

[13] Jeng-Shing W.,Wen-Ping H., 2009. The effects of a Swimming Intervention for Children with Asthma. Respirology,14, 838-842 doi: 10.1111/ j.1440 -1843.

[14] Jennifer R., Pharr., 2014. Parental Factors That Influence Swimming in Children and Adolescents. International. Journal of Aquatic
Research and Education, 8, 368-381 http://dx.doi.org/10.1123/ijare.2014-0041

[15] Lori A. Sherlock, W. Guyton, Hornsby, Jr., and James Rye, 2013. Physiological Effects of Aquatic Exercise on Cognitive Function in the Aging Population. International Journal of Aquatic Research and Education, 7, 266-278 (C) 2013 Human Kinetics, Inc

[16] McGovern, 2005. The Effects of Exercise on the Brain. Biology 202.Serendip.

[17] Mangunnegoro, Hadiarato dkk., 2004. Asma Pedoman Diagnosis \&Penatalaksanaan Di Indonesia. Jakarta: Perhimpunan Dokter Paru Indonesia.

[18] Masrizal Dt., Mangguang, 2016. Faktor Risiko Kejadian Asma Pada Anak Di Kota Padang.Arc. Com. Health. Issn: 2527-3620. Vol. 3 No. $1: 1$ 7

[19] Matsumoto, H Araki, K Tsuda, at al., 1999. EVects of swimming training on aerobic capacity and exercise induced bronchoconstriction in children with bronchial asthma.Journal of Exercise Science and Fitness. Original articles. Thorax;54:196 \pm 201

[20] Nugroho, Sigit, 2008. Terapi Pernapasan Pada Penderita Asma, Fakultas Ilmu Keolahragaan, Universitas Yogyakarta.

[21] Pedersen L, Lund TK, Barnes PJ, Kharitonov SA, Backer V., 2008. Airway Responsiveness and Inflammation In Adolescent Elite Swimmers. J Allergy Clin Immunol;122:322327.

[22] Persatuan Dokter Paru Indonesia, 2003. "Asma: Pedoman diagnosis dan Penatalaksanaan di Indonesia." Jakarta: PDPI.

[23] Pohan YH., Yunus F., dan Wiyono WH., 2003. Asma dan Polusi Udara. Maj. Cermin Dunia Kedokteran [online];141:27-9.

Dari:http://www.kalbe.co.id/...AsmadanPolusi Udara.../09 Asma dan Polusi Udara.

[24] Ram, F., S., F., Robinson, S., M., Black, P., N., Picot, J., 2005. Physical Training For Asthma. http://www. cochrane. org/reviews/en/ab001116.html.

[25] Ratih Oemiati, Marice Sihombing, Qomariah, 2010. Faktor-Faktor Yang Berhubungan Dengan Penyakit Asma Di Indonesi. Media Litbang Kesehatan Volume nomor 1 Tahun 2010.

[26] Ray AD., Pendergast DR., Lundgren CE., 2008. Respiratory muscle training improves swimming endurance at depth. European Journal of Applied Physiology, DOI: 10.1007/s00421-0060359-6, ISSN: 1439-6319 (Print) 1439-6327 (Online).

[27] Rogayah, R., 1999. Pengaruh Penyuluhan dan senam Indonesia terhadap pengetahuan, sikap, 
perilaku dan gejala klini pasien asma. Jurnal

Respir Indonesia Paru, 116-124.

[29] Shaffer TH., Wolfson MR., dan Bhutani VK., 2012. Respiratory Muscle Function Assesment And Training. United States Of America : Physical Therapy Journal Of The American Physical Therapy Association.

[30] Sheikh, et al., 2000. Can Peak Expiratory Flow Predict Airflow Obstruction in Children With Asthma? Pediatrics. Volume 105/Issue. Hal: 105:354-8.

[31] Sundaru, H., 2007. Asma (Apa dan bagaimana pengobatanya). Jakarta: Balai Penerbit FK UI.

[32] Supriyatno, B., 2005. Diagnosis dan penatalaksaaan terkini asma pada anak, MKI, vol 55 no 3, Maret 2005.

[33] Undang-Undang Republik Indonesia Nomor 36 Tahun, 2009. Tentang Kesehatan.

[34] WHO., 2006. Asthma. alveilebel in http://www.who.int/topics/asthma.

[35] Wong, D.,L., 2003. Pedoman klinis keperawatan pediatrik. Terjemahan oleh Monica Ester. Edisi ke-4. Jakarta: EGC.

[36] Yusuf, F., 2007. Asma jangan dianggap enteng. Dewan Asma Indonesia, FKUI. 